A list of Working Papers on the last pages

No. 262,1990

DEREGULATION, INNOVATIVE ENTRY

AND STRUCTURAL DIVERSITY AS A

SOURCE OF STABLE AND RAPID

ECONOMIC GROWTH

by

Gunnar Eliasson

This is a preliminary paper. It is intended for private circulation and should not be quoted or referred to in publications without permission of the author. Comments are welcome. 
90-08-02 GE/714, Innovative entry

\title{
DEREGULATION, INNOVATIVE ENTRY AND \\ STRUCTURAL DIVERSITY AS A SOURCE OF STABLE AND RAPID ECONOMIC GROWTH ${ }^{1}$
}

\author{
By Gunnar Eliasson
}

\begin{abstract}
The importance of free innovative entry (deregulation) for diversity of structure and competition is studied. I demonstrate quantitatively that even with a narrow definition of entry (firms), and given observed entry behavior, successful entrants completely dominate the long run performance characteristics of the economy. Rapid and stable long-run macro economic growth can only be achieved if innovative competitive entry is vigorous. Free access to markets is a necessary condition, competence a sufficient condition. It is probably wrong to believe that the (ex ante) threat of entry is sufficient for dynamic competition. A growing economy requires a steady showering with optimistic entrants, a few of which turn out ex post to be superior performers. Failing and exiting firms are part of the innovation costs to society for steady and rapid economic growth. The benefits of financial innovations like junk bonds are to reduce barriers to competitive entry to make both successes and failures possible.
\end{abstract}

1 I am very grateful to Pavel Pelikan and Frank Stafford for many constructive comments on earlier drafts of this paper. All remaining errors are, however, entirely of my own making. 


\section{Taking off the Lid - formulating the problem}

Some time ago I accidentally opened an old book (Lundell 1846) on the dismantling of the craft guild system in 19th century Europe. It was fascinating reading. Lundell gave an account of what had been going on in Europe during the last (before 1846) half century. A few decades later the industrial revolution was in full bloom, but only in those countries where by Lundell's account - the "lid had been taken off" and free competitive entry established as the rule of the game. Those countries that had adopted that rule, later became the wealthy industrialized nations. The others did not.

Adam Smith is best known for his emphasis on work specialization and market coordination (the invisible hand) as the source of economic growth and the welfare of nations. Adam Smith, however, stands for much more than that. He may in fact (Andersen-Tollison 1982) have been very misinterpreted by modern scholars in their search for easily formalized and teachable models.

Adam Smith saw freedom of entry as the main source of competition and the rivalrous market process, that was in turn the source of economic growth. This is what Adam Smith observed was going on around him in the early phases of the industrial revolution.

This is why the deregulation in Eastern Europe is so interesting today, more interesting than Europe 1992, since the outcome of Europe 1992 largely depends on a political process still to be realized.

This paper is concerned with the importance of innovative entry for economic growth. Our discussion is broadly conceived, including new product "entry" as well as new firm entry and entry through mergers and acquisitions. The empirical application will, however, be more narrowly quantified. This means that the results on innovative entry, even though striking will be underestimated. It is remarkable that this side of the Smithian heritage has been weeded out efficiently by those who claim to model the invisible hand at work. No wonder that economists have difficulties explaining the onset and the disappearance of economic growth. 
As pointed out by Morishima-Cathephores (1988) the Smithian heritage split into two lines with Ricardo, or perhaps more adequately with Walras (1874). Walras was in fact concerned with the entrepreneur, but did not succeed in integrating him within his equation system. This formalized system is what modern general equilibrium theory is based on, its most prominent representatives being Kenneth Arrow and Gerhard Debreu. The success of the Walras-Arrow-Debreu (I call it the WAD) story hinges on its remarkable communicability - in teaching in particular - through a transparent mathematical formulation.

The other line goes by way of the Austrian school, Karl Menger (1872), Eugen von Böhm-Bawerk (1881) and with Joseph Schumpeter (1911) as its towering figure, making the innovative entrepreneurs the central, unpredictable actors. As pointed out by Dahmén-Eliasson (1980) and Morishima-Cathephores (1988) this leads right up to the disequilibrium economics of Wicksell (1988) and "Anti-Says law". The Smith-Schumpeter-Wicksell connection - I call it the SSW tradition - is more genuinely original Adam Smith. It has, however, not been successfully propagated through the profession. It has yet to be formulated mathematically and it is difficult to communicate efficiently in short articles, or in the classroom. This again means that financial innovations, or rather the bankers' role of coordinating savings and investment "conceptualizes a departure from the world of Say's law". This is perhaps the most innovative contribution of Schumpeter. It almost completely prepared the way for the Keynsian Revolution (Morishima-Cathephores, 1988, p. 26. Also see Day 1986).

John Bates Clark's (1887) idea of "potential competition" was an attempt to revive the Smithian tradition. Clark's idea has been formalized and "refined" by Baumol-Panzar-Willig (1982) under the name "contestable markets". The WAD researchers have all felt the need to deal with innovations and entry. A few well known early attempts are Arrow (1962) on innovations and Jenner (1966) on new entry. There is also a host of recent game theoretic articles on $R \& D$ races in the static equilibrium tradition (see Reinganum 1989), that I won't review here. The problem is that such attempts - if 
modeled in the SSW tradition-disrupt the mathematical and educational elegance of the WAD model. Hence, very little has been done, and what little has been done has not been very convincing, even though a series of attempts can be reported from the last few years (see below).

My position on this, to which I now turn, is that economic dynamics has to be based on the SSW paradigm to be economically meaningful. This is, however, intellectually very disruptive. And until a new mathematics based on the grammar of computer languages has been developed, SSW analysis of economic systems probably has to be in the form of numerical analysis ${ }^{2}$. The micro-to-macro model of the Swedish economy (Eliasson 1977, 1978, 1984, 1985,1988 etc) is such a model in the SSW tradition. The Nelson-Winter (1982) evolutionary model another. In this paper I will use the Swedish microto-macro model to demonstrate the necessity of innovative activity to maintain sufficient structural diversity for a stable, out of equilibrium growth process to be feasible. Some insight into the long run consequences of large scale deregulation of markets comes as an extra.

\section{New and old attempts to model new entry}

After Modigliani's (1958) review article on oligopoly theory the field became dominated by the prior view that monopoly power was determined by the relative size of the minimum effective plant the cost disadvantage of sub minimum size production and the elasticity of demand. Hence, entry almost became irrelevant. Only the above determinants of the limit entry price merited attention. Since entry came from new, inexperienced firms with a cost disadvantage, it was assumed, the limit price would stay above long run average costs, despite entry. Thus, observes Baldwin-Gorecki (1987) it is not surprising that so few empirical studies have been devoted to new entry, and that, until recently, theoretical interest has been lukewarm.

2 In fact static game theoretic modelling of particular aspects on innovation and entry has fragmented into an even more bountiful plethora of possible conjectures than produced by numerical analysis, and for the same reason. It is comforting to note that theorists finally have to accept that theoretical conclusions have to be pinpointed on the basis of empirical knowledge. 
Jenner (1966) is an early attempt to introduce entry in the classical model. He follows Marshal and observes that the significant condition in the classical model is that no firm dominates the conditions under which a new product emerges, not that it is unable to control the price of its output. Jenner makes product differentiation a necessary condition for product competition and concludes that monopolies may be created internally (on the basis of product developments) in the competitive system, that they are not inconsistent with pure competition, since they are continuously controlled by competitive forces, and in fact are part of the competitive process.

This whole idea is very Schumpeterian in spirit, but neither Jenner, nor anyone else has worked it out mathematically. The idea is not consistent with the classical model. Jenner (1966) in one sense was a forerunner of the contestable market story. Jenner's analysis was, however, much more broadly conceived. He did not limit attention to new firm entry, but studied what mattered for price competition. He also studied actual competition. With this, unfortunately Jenner more or less vanishes from the reference lists. Part of the Jenner approach reemerges in the "product selection, fixed cost" analysis of Spence (1976). While observing that fixed costs and heterogenous product qualities create multiple market equilibria Spence's analysis is still welfare analysis based on static equilibrium. Both Jenner and Spence, however, argue an important point, namely that entry and market behavior is first and foremost a matter of product introduction, and only secondly a matter of the establishment of new and more cost-efficient production plants. There is far more growth generating entry than revealed by new plant and firm entry into existing product lines.

The contestable market (Baumol 1982, Baumol-Panzar-Willig 1982) story asserts that threat of entry in existing product lines is sufficient to force incumbents to produce at long run average costs. It has been challenged by many. To be observed in the context of this article is Sheperd's (1984) argument, that new entrants are initially small and cannot initially challenge the incumbents' share of the market. The effects of entry comes from their long run growth. 
What I want to emphasize is that new entrants come in all shapes and forms. Some are badly equipped, some are very efficient, but most fail. Hence looking at only new plant or firm entry both underestimates the extent of new entry and its long term effects. The large number of competitive entrants, some of which turn out to provide competition in related product lines refutes both the original Modigliani as well as the contestable market stories. Serendipitous competition from seemingly innocent challengers may turn out to be much more important a competitive threat than head-on price competiton in the same market niche. ${ }^{3}$ Such competiton may lure the critical, high end customers away, like cellular phones from the regular network, or volume servings of fast food outlets at critical hours from restaurants. The $\mathrm{PC}$ is an even better serendipitous competitor that is now - not much more than a decade after its introducton - threatening the mainframe business, after having killed, through 4 its workstation version, the minicomputer business. Actual entry here is what matters for competition. In the long run this paper shows - those superior, surviving entrants are decisive for the macro economic performance of the economy. Therefore, restricting entry reduces both competition and macro economic growth.

${ }^{3}$ I owe the formulation to Frank Stafford and a fruitful discussion at IUI.

${ }^{4}$ See Eliasson (1990a). 
Dasgupta-Stiglitz (1981) observe the same deficiency of the classical model as Jenner and build a model which makes both industrial structure and technical change endogenous. They, however, declare as their interest analysis of steady states. To do this they assume the (compensated) market demand curve to be iso-elastic and make exogenous growth in demand both the price setting and the driving force behind innovative activity. An exogenous flow of best practice process technology is then tapped by firms at a rate determined by the trade off between the decline in unit (variable) costs of production in best practice plants and the increase in (one shot) innovation costs. They then demonstrate that the "long-run growth in output along a steady state is independent of industrial organization", even though "industrial organizations may differ with respect to the frequency and magnitude of innovations undertaken within them". They achieve that result by carefully crafting assumptions such that path dependence is avoided. The assumed perfect capital market is critical, since it forces the worst firm to exit when a best practice firm enters, thus keeping the number of firms constant. It is all very neoclassical with production technology assumed known, even though the authors claim they are capturing the Schumpeterian view of competition and "creative destruction" the way Schumpeter would have liked to see it done.

Models very similarly structured to Dasgupta-Stiglitz (1981) were formulated (in Swedish) by Du Rietz (1980) and Englund (1980) and later elaborated in Eriksson (1984) and Hause-Du Rietz (1984). This analysis is formulated in terms of cost efficient plant entry, and does not address the problem of how innovative entry and macro economic growth interact.

Jovanowitch-Lach (1989) break partly away from the restrictive, steady state framework, still cleverly staying within neoclassical mathematics. The trick is that with (assumed) perfect foresight à la Arrow (1962) learning by doing creates predictable, differentiable qualities of agents. J-L observe that "probit-type" or "epidemic" models exhibit S-type diffusion paths of innovation if heterogeneity among adopters is assumed. They note that game theoretic models have concentrated on the classical tradition of proving the existence of a diffusion process and continue to show that homogeneous agents can acquire the needed heterogeneity through learning by doing. New 
entrants incur a fixed entry cost, that decreases through learning by doing. These cost advantages are appropriated by later entrants. Entry drives down costs and prices and eventually also the temporary monopoly profits earned by the early entrants, who eventually exit. Hence (exogenous) learning-bydoing cost reductions drive the model which stabilizes on an equilibrium entry path, where entry is proportional to the current flow of profits. Investment in new technology is in turn proportional to the volume of innovative entry. J-L learn that there is a trade off in the form of higher margins for early entry and lower margins (lower unit costs) from later entry. Since perfect foresights rules, an equilibrium growth path can be demonstrated to exist. A monopolist will innovate less than a competitive industry, but sooner, and the sooner relatively (and better for welfare) the higher the discount rate. By assuming learning-by-doing to occur in the form of cost saving entry improvements, J-L of course find that the monopolists through innovating or entering early and appropriating cost savings - "do better" for social welfare, if demand is sufficiently elastic, than perfect competition does. They associate this results with Schumpeter, who, however would not have recognized their neoclassical, perfect foresight framework.

The essence of innovative entry in contrast to these models is that firms entering the market in reality have both unclear expectations about the growth situation in the market and the potential of their innovations, and that the growth situation in the market has to depend on what each firm expects all other firms to do. Hence, incumbents definitely do not face "computable destruction" as in the J-L model. Perfect foresight or some kind of stochastic, rational expectations assumption (like Lucas 1976), together with rather strongly convex adjustment cost functions, both to contain growth of existing firms and to regulate the rate of entry, are needed to stay within the neoclassical framework. Without such assumptions both the rate of entry and the production volume of existing firms cannot be determined. This, however, has nothing to do with innovative activity and the kind of dynamic competition Schumpeter visualized verbally, which seems to be absent in the Anglo-Saxon industrial organization tradition (de Jong 1989). Above all, the whole distribution of outcomes, which includes mistaken innovative decisions, are as important a driving force as neoclassical cost saving. 
Schumpeterian innovative entry and creative destruction is as far removed from the corresponding computable and predictable activity of the general equilibrium based steady state model as one could imagine. To begin with such a model should at least exhibit games with a variable number of firms and be typically path dependent, and thus be completely outside the rational expectations class of steady state models (see Eliasson 1989).

\section{Empirical studies}

Speculation on what entry and exit mean for macro economic performance is abundant. (We look at why firms enter in the next section). Empirical studies are few. They require effort and enduring research patience. Above all, the entry definition that is relevant in a growth context is extremely broad and takes you down to the product innovation level. But even if you opt for a cruder and more traditional approach it is extremely difficult and costly to follow a panel of newly established firms for much more than a few years. And if you include diversifying entry or product innovations within existing firms the problem escalates.

\section{$\underline{\text { Innovative entry and Market Competition }}$}

One of the early and more enduring such research efforts was Du Rietz (1975, 1980) on Swedish data. Du Rietz and later Hause-Du Rietz (1984) conclude that potential entry really is not sufficient to support dynamic Smithian-Clark competition. Actual and significant competitive entry is needed. From a series of papers by Acs-Audretsch (and vice versa) a fairly comprehensive picture (or rather hypothesis) of the innovative entry process can be pieced together. First of all Acs-Audretsch (1987) observe, - testing the Schumpeterian (1942) hypothesis of routinized R\&D in large firms - that large firms exhibit an innovative advantage in imperfectly competitive markets, while small firms do best in more competitive markets, with many small firms. A-A conclude that the question "Which firm size is most conductive to innovative activity?" is the wrong question to ask. It should 
rather be "Under which circumstances do large or small firms have a relative innovative advantage?" They continue in A-A (1988) and conclude that the number of measured innovations is negatively correlated to concentration (cf Stigler 1968) and unionization but positively related to $R \& D$, albeit at a decreasing rate. They also find (1989b) that new firm births are strongly related to profitability and industry growth, but neither capital intensity nor small firm cost disadvantages relate to birth. Small-firm births are inhibited in concentrated, advertising intensive markets, that use human capital intensively and are highly innovative, and vice versa for large firms. Innovation is, however, represented by measurable innovations, a proxy with a typical large firm bias. These results are further elaborated in (1989a) on small firm entry characteristics, where entry barriers do inhibit entry, but that scale disadvantages have been diminishing, especially if firms are able "to implement a strategy of innovation". R\&D intensity and market concentration, again deter small firm entry.

Putting all these bits and pieces together in one context is very informative. The conclusion is that competition plays a role in determining the entry characteristics of the market, but that competition also depends on entry. Entry is regulated by the competition of incumbents, that depends, as we have seen, on large fixed costs and other monopoly characteristics, including regulation. To capture this dynamic interaction you need a full scale microbased macro model with entry and exit explicit: This interaction dynamics is usually exogenized in partial models. In a full scale model you have to identify empirically the ultimate driving force, like "learning by doing" in the Jovanowithch-Lach (1989) model, or exogenous flows of innovations, as in Winter (1984). However we do it, the empirical and analytical results take us back to the original (1911) Schumpeter hypothesis of the unpredictable entrepreneur, that learns and innovates, and the experimental nature of the growth process, micro failure being more typical of macro economic success than vice versa. 


\section{Firm turnover and macro economic growth}

Conventional wisdom has been (see eg. Eriksson 1984, p. 52) that "industry growth comes mainly from existing firms". This is either a trivial conclusion or a reflection of the short-term nature of economic analysis. Over a decade or two the volume of output, including growth in output must originate in firms existing at the beginning of that period. Over longer periods surviving new entrants begin to dominate in the growth process and, above all, firms change the content of their operations. After a decade or two new products definitely dominate macro economic growth. Hence, while entry and exit may not affect macro variables in the short-term, they matter increasingly in the long term. It takes a shower of new entrants to attain a visible presence of a few after many years. Most "experiments" fail in a twenty year time perspective. All new firm entrants (Du Rietz 1975, 1980, p. 17, 20) in Swedish manufacturing (39 sectors) 1954-68 made up 6.3 percent of total employment in 1968. Employment growth in the group of new entrants was significantly higher - during the same 15 year period - than the industry average. Diversifying entry of large firms furthermore, has to be included to capture the whole growth process. Finally, identifying new entry with a new firm or a new plant, as is always the approach in empirical studies, may be misleading. A new product, for instance a new automobile model, may or may not be associated with the building of a new plant to produce it. It is the introduction of new products that matters for competition and growth, not the establishment of new plants, which is what Jenner (1966) suggested.

Most new firm entrants succumb in the competitive process. Granstrand (1986) reports that the average new entrant is not better than incumbent firms in terms of productivity or other performance characteristics. The spread is, however, very large. Baldwin-Gorecki report a cascade of results on the entry and exit process in Canadian manufacturing that illustrate the quantitative long run significance of the firm turnover process. The job turnover consequences (B-G 1989a, b) are sizable, entry adding (1971-1983) 6.2 percent to the stock of firms and 2.3 percent to the number of jobs annually. Since 6.8 percent of the number of firms exited annually together with 3.4 percent of the number of jobs the net appears to be on the negative 
side. Mergers and acquisitions (B-G 1987, 1990b), however covered the difference, suggesting that if data on mergers are not available, great care should be taken in interpreting the results. This is also collaborated in Eliasson (1988). Average labor productivity of surviving greenfield entrants is found (in B-G, 1990a) to be only 73 percent of incumbents. After a decade, productivity of survivors, however, is on par with productivity of incumbents. In fact; Jagrén (1988, p. 259 ff) reports that among already established firms (a random sample of 115) from a register of medium sized and large firms in 1920 , only 21 remained as independent firms by 1980 . And it took 25 years, on the average, for the firms that survived and became large, to reach the size of 1000 employees (op.cit. p. 245). Baldwin-Gorecki (1988) conclude that 18 percent of labor productivity growth in Canadian Manufacturing during the 70 s could be attributed to firm entry and exit. Baldwin-Gorecki (1990a) report that average plant size of greenfield entrants begins at about 17 percent of that of existing firms, and even a decade later is equal to just 33 percent of the size of the initial incumbents.

\section{Other empirical results}

Several additional but not as ambitious studies on firm entry have been published. Dunne-Roberts-Samuelson (1988) use a newly compiled data set on US entry and exit over a 20 year period, that allows them to distinguish between new entrants, diversifying entrants and existing firms that alter the mix of outputs such that they change four digit classification and to study how correlation patterns between exit and entry rates look over time. They find that diversifying entrants are generally larger and survive longer than new entrants. They also find that the market share of each entry cohort declines as the cohort ages, because of high exit rates that overwhelm the increase in output of surviving firms (cf Jagrén 1988). They also observe a substantial heterogeneity in both initial and post entry characteristics of entrants and a strong correlation between entry and exit across industries, indicating that industries differ significantly in their degree of firm turnover. 
The conclusion so far is that entry matters quantitatively for macro economic growth. The question is how much. The answer comes in two parts; (1) what incentives move entry and exit, about which we can draw some conclusions from the reported studies; (2) once we know the incentive mechanisms for entry, what are the total systems effects at the macro level?

\section{Incentives for new entry}

I opened with the question of what free innovative entry means for competition, structural diversity and the stability of the macro economic growth process. The Smithian postulate was that free entry checks monopoly formation and tendencies towards concentration. Schumpeter (1911) added that innovative entry fuelled the growth process and forced low performers to exit (creative destruction). Later (1942), observing the growing efficiency of large combines engaging in routinized industrial research, he worried about the inevitability of concentration, private monopolies that teamed up with the state, and the decline of democracy. This worry is mathematically synonymous to the scale problem of the static equilibrium model. This paper suggests that we do not have to worry as long as we realize the role of dynamic, free entry and the competence to innovate is around. Markets will then exercise an endogenous self discipline on monopoly formation. If the competence to innovate is lacking, foreign competition exerts the same discipline (Eliasson 1987).

Dynamic markets rule out capital market equilibrium. Dynamic markets are moved by unconstrained innovative entry and exit. To illustrate, let me outline the dynamics of the Swedish micro-to-macro model, in which performance characteristics of the market are expressed in terms of e.g. productivity and rate of return distributions (Salter curves), the potential shapes of which determine intensity of competition, and hence, also prices. The potential shape of the Salter distributions change through a number of endogenous factors and entry, which raises the upper left, high performance end (see Figure 2) and - as a consequence also force exit (creative destruction) at the right, low end. Both Dunne et al (1988) and 
Baldwin-Gorecki (1990e) report a positive correlation between entry and exit. The total systems effect on quantities and prices in a dynamic general multi market setting is complex enough to rule out predictability at the micro level, in the risk based insurance sense of modern IO literature.

The importance of this structural and price feedback for macro economic growth performance is the problem addressed specifically in this paper. I have studied it quantitatively within the framework ("structure") of the Swedish micro-to-macro model. Mergers and acquisitions is an additional structure disrupting factor that has been pointed out in several empirical studies that we (so far) have not modeled within the micro-to-macro model. Adding mergers and disaggregating to the product level will, I believe, strengthen the quantitative simulation results.

Entry in itself has now been established as a growth creating factor.

New entry, however, does not occur out of the blue. Incentives have to exist. In discussing entry I can think of three moving forces: expected excess profits in the market (monopoly profit) from a new product or cost-reducing process Deteriorating industrial performance, makes it easy for the new entrant to be profitable by being better.

Extreme "technological" diversity and competition enhances the potential for innovative new combinations, if you are good.

The first proposition makes the entering entrepreneur a trader à la Kirzner, 1973 who equilibrates the economy. The second type entrepreneur rather changes the parameters of the system because lack of good competitors makes it easier. This is a weak Schumpeterian proposition. The third type of entrepreneur is more typically Schumpeterian, or Darwinian who is driven by superior competence, and thrives on the opportunities for new, innovative 
combinations provided by diversity (Eliasson 1988). The structure or the parameters of the system are changed as a consequence of their activities.

The third proposition - as it is formulated - may required some clarification (see further Eliasson 1990b). An extremely varied economic environment enhances potential competition, partly because such an environment exhibit more spread behavor the best and the worst, and partly because the diversity as such increased the potential for learning and for finding new combinations. The latter is a kind of Silicon Valley effect. The enhanced potential for competition, however, of course also means an enhanced potential for learning, innovation and entering, if there is sufficient competence to exploit such a rich environment. This also gives content to the second type of entry inducement. If the economic environment is declining, external, competent entry candidates perhaps having "learned" elsewhere (for instance in Japan) may find it easier to enter and make a profit, than in a type 131 environment.

These three hypotheses are distinctly different but very difficult both to model and to test. In current literature they have all collapsed into one and the same formulation in which market growth and/or profitability drive new entry over time. Both market growth and profitability, however, depend on entry. Mansfield (1962) reports a positive correlation between firm entry and industry (market) profitability, as do Baldwin-Gorecki (1987, p. 35), Schwalback (1987), Highfield-Smiley (1987), Acs-Audretsch (1989a) etc. H-S (1987) mention an interesting difference between macro (timeseries) and cross sectional behavior, observed partly already by Dahmén (1950). New business starts appear to increase in bad times (slow growth), while - in a cross section - they relate positively to market growth and market rates of return.

I won't be able to contribute anything beyond what others have done on the incentives behind innovative new entry, except that they are normally assumed to be based on an expected excess rate of return formulation that is compatible with all three explanations above. The new thing is the micro-macro - micro analysis embodying a path dependent (not a steady state) endogenous model structure with price feed back in which new entry 
preserves the structural diversity needed for viable competition, in turn needed to prevent concentration.

\section{Diversity of Structure needed for stable and fast growth in output}

It was observed in Eliasson $(1983,1984)$ that with no entry but exit of low performers a strong long run tendency towards market concentration emerged. Competitive exit without entry forced remaining firms to be as good as, or better than all other firms - or exit. Fewer and fewer firms looking very much alike as to performance characteristics began to dominate as the economy moved closer to a static equilibrium in the capital market, with flat Salter curves (Hypothesis 2 above). This was the worry of Schumpeter (1942). Another worry is that such an organization of the economy is not economically viable. It exhibits (in the simulation) all the characteristics of efficient flow coordination of the economy but also an increasingly, potentially unstable situation, because of the absence of buffers or slack to absorb disturbances. The model economy eventually collapsed because of an internal disturbance and the long run (50 year) outcome in terms of growth in output turned out below the result in a simulation with a less frantic pace in the early phases. Our hypothesis (see Eliasson 1984) has been that an efficient flow coordination of the economy requires a steady inflow of new entrants to keep up diversity of structure. ${ }^{5}$ The more of innovative entry the faster substainable growth possible. This slack, like exit of failures is a cost for growth in the experimentally organized economy. Innovative entry, so to speak keeps the economy away from "static equilibrium".

\footnotetext{
5 This diversity should be interpreted broadly to be augmented by all forms of entry (cost improvements, new products, new firms etc) even though the model experiments I refer to include only new cost-efficiency improving firm entry. For simplicity we may interprete - in this context - structural diversity in terms of Salter-productivity distributions, even though a number of additional performance charachteristics come into play both in reality and in the model. The entry feature, in fact, was in the model from the beginning and generated the expected results. (Eliasson 1978, pp. $52 \mathrm{ff}$ ) At the time having consulted economic litterature - we did not consider entry that important for macro economic growth, so we closed down the entry module. It has later been updated and made more sophisticated (see Hansen 1986, 1988).
} 
Hanson (1986) introduced new entry and demonstrated that productivity and growth performance increased in the very long run (Figures 1A, B). For practical reasons there was no time to elaborate those results. I have now re-run his experiment and computed the distributional characteristics in mid-term during the simulation with and without new entry, i.e. about the time of the collapse.

The entry experiments tell what happens in the long run with a protected industry when a previously regulated market is opened up to free competitive entry. 6

Competitive entry consists of new firms which - in the experiment - on average exhibit the same average cost performance characteristics as the average incumbent; but a larger spread (see Hanson (1986)). For computer practical reasons the number of entrants had to be rather small ${ }^{7}$ to allow the very long "historic" simulation needed to see effects. The results (see Figure 2) strongly support the SSW tradition of thinking and the hypothesized need (Eliasson 1984) for new entry to maintain structural diversity and macro economic stability. On the 30 year horizon the upper left hand part of the distribution is dominated by the new entrants. If you plot the remaining firms from the initial state only, 30 years later the structure is much flatter and lacks high performers. Even more interesting is the re-run of the same experiment with no entry and (hence) less competition. On the 30 year horizon much less diversity is exhibited, and the remaining larger number of (initial) firms is performing significantly below the level of the smaller number of remaining (initial) firms in the competitive entry case.

The macro productivity effects are, however, almost negligible for a very long time (Figures 1,2) eventually to exhibit themselves. This illustrates the problem, that there is a cost of "static inefficiency", represented by the slope

6 With the qualification that the initial state year 0 is one of a very competitive industry, since data on Swedish manufacturing firms are used.

7 So as not to fill up work space with too many firms too soon. 
and shape of the Salter distributions, associated with sustainable long term, stable growth in aggregate output.

One may wonder why both the new entry runs in Figures 1 perform below the no entry case for many "intermediate" years and that the cycle in output (Figure 1B) becomes damped. The reason, is the development of "slack" in the entry case which means that capacity ceilings are much further away than in the no entry case and that a smaller part of the firm population is hurt and/or exits 8 in the down swing, all depending on the slope of the productivity distributions in Figure 2. These are numerical illustrations that make verbally expressed ideas visible in a concrete way. The results are that entry dominates industrial structure in the very long run, but that the results do not show significantly in the short run. They show up if you are able to follow a panel of firms for a decade or so as in the early Du Rietz $(1975,1980)$ and in the Baldwin-Gorecki studies. The longer the panel, however, the more the identity of the entrant diffuses. The benefit of the economy wide simulation technique is that well defined entrants and exits can be followed, their behavior being tuned to what we think we know about entry and exit behavior. Since such entry underestimates total entry activity at lower aggregation levels than the firm, we can also confidently believe that our results underestimate the quantitative importance of entry and exit for economic growth.

\section{Conclusions on the macro economic consequences of deregulation}

The essence of a free market in terms used by economists like Smith and Schumpeter (the SSW tradition) is that free competitive entry is the rule of the market game. We have demonstrated by way of numerical simulations on a dynamic micro to macro model that taking the lid off an economy closed to competition from new entrants improves the long run performance of the economy, very much as Adam Smith argued a very long time ago. In this

8 Exit occurs in the model, when firms have been unable to meet rate of return targets for a long period and/or when they run out of networth. 
sense, removing barriers to trade would have the same effect as removing barriers to entry.

Competition among firms is the engine of economic growth. Without innovations, broadly defined, however, intense competition (fast markets) soon erodes the diversity of structures needed to maintain rapid and stable macro economic growth. The closer to static equilibrium the more latently unstable the economy. To maintain fast long-term economic growth the diversity of structure needed has to be maintained through rapid innovative entry in new products and cost reducing innovations. The key factors behind long-run economic growth then become three; that incentives to new innovative entry are sufficient, that competence to compete efficiently is abundantly available and that the competitive spirit is present. 
Figure 1

Productivity and production growth in two parallel simulation experiments - with and without competitive entry.

Figure 1A The impact of entry on productivity

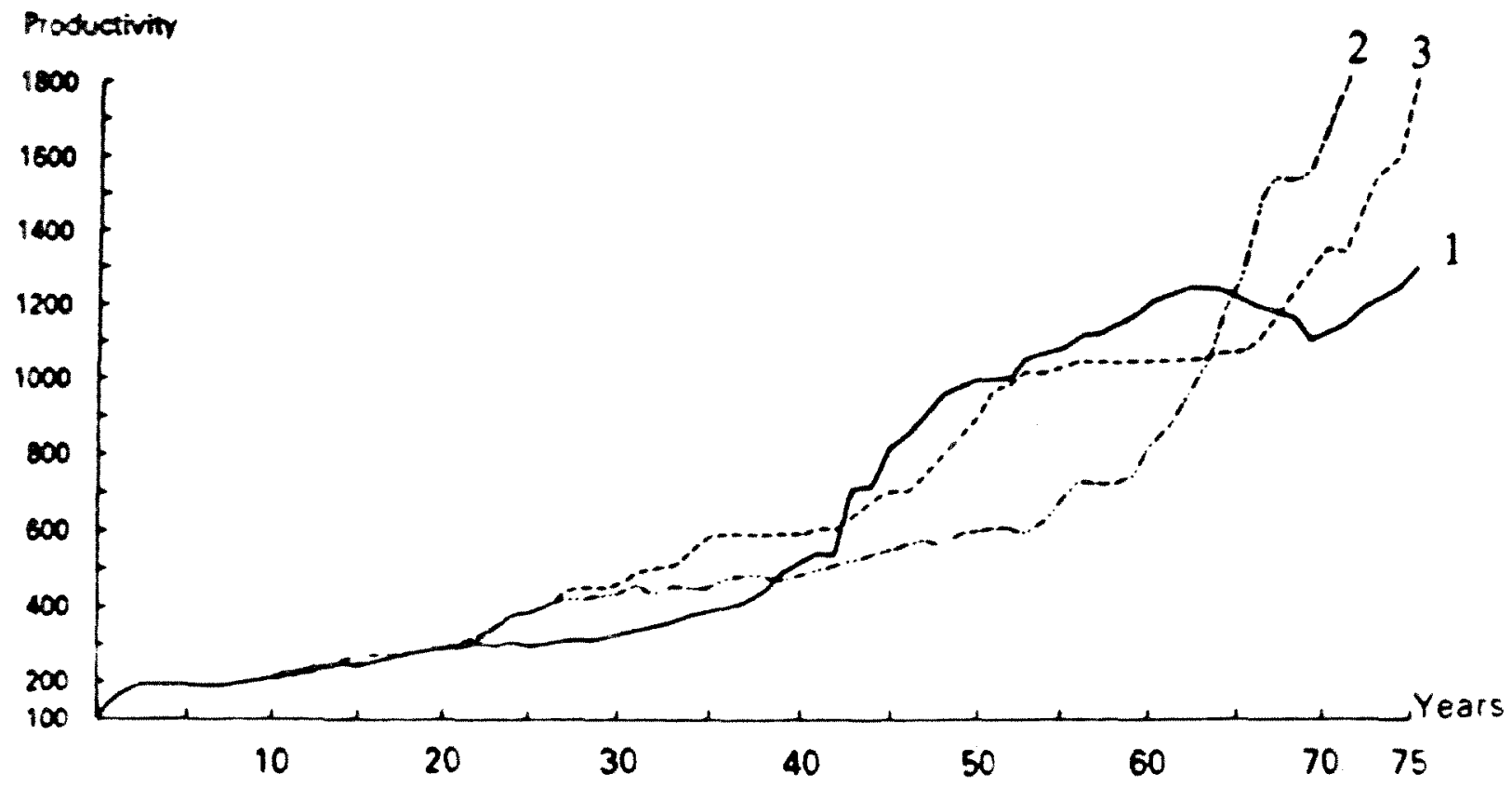

$1=$ No entry

$2=$ Normal productivity entry

3 = High productivity entry 
Figure 1B The impact of entry on production

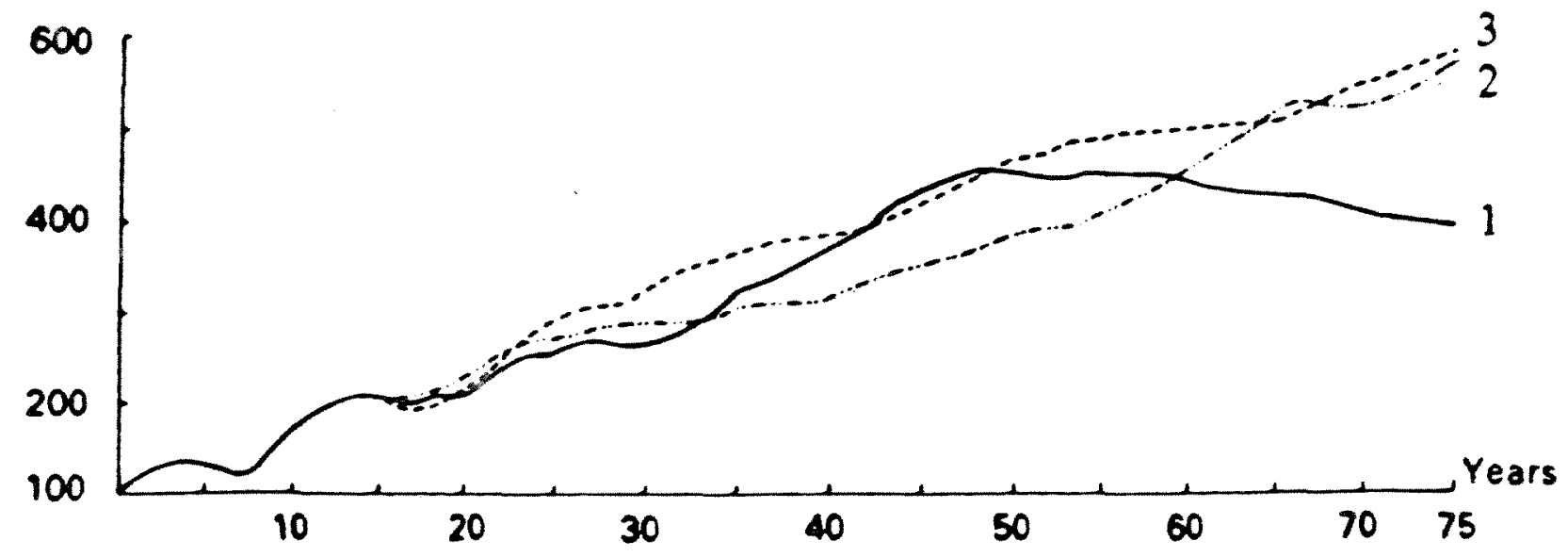

$$
\begin{aligned}
& 1=\text { No entry } \\
& 2=\text { Normal productivity entry } \\
& 3=\text { High productivity entry }
\end{aligned}
$$

Source: Hanson (1986, p. 66 and 68$)$ 
Figure 2 Productivity distributions (Salter curves) after 30 years in new entry and no entry cases

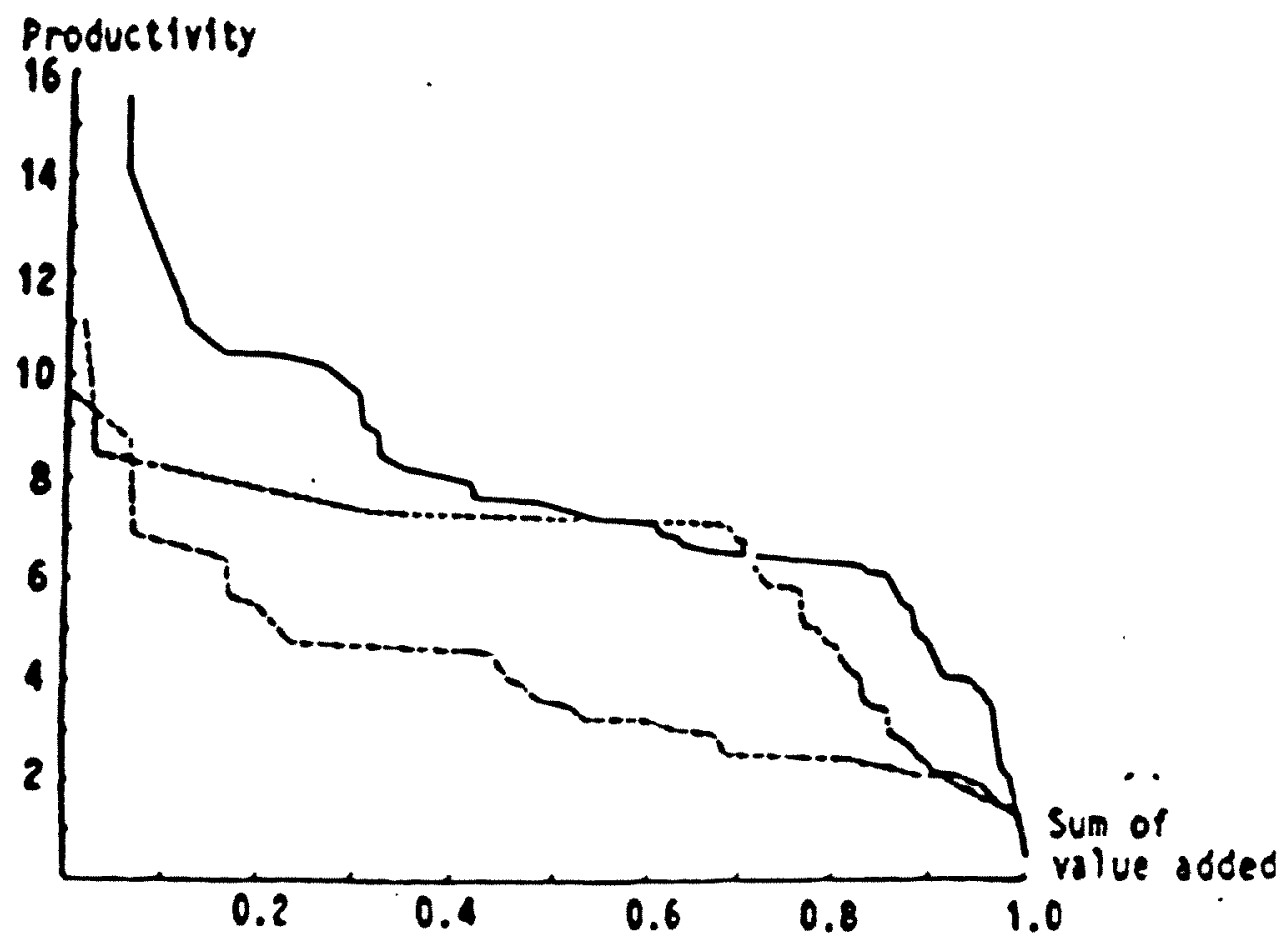

all firms in year 30 , including new entrants remaining original (year 0 ) firms only all firms in year 30 in simulation experiment with no entry, everything else the same

$1=$ No entry

$2=$ Normal productivity entry

3 = High productivity entry 
Bibliography

Acs, Z.J.-Audretsch, D.B., 1987, Innovation, Market Structure and Firm Size, Review of Economics and Statistics 69 (Nov.) pp. 567-575.

Acs, Z.J.-Audretsch, D.B., 1988, Innovations in Large and Small Firms: An Engineering Analysis, AER 78 (Sept.) pp. 678-690.

Acs, Z.J.-Audretsch, D.B., 1989a, Small Firm Entry in U.S. Manufacturing Economica 56(2), May.

Acs, Z.J.-Audretsch, D.B., 1989b, Birth and Firm Size, Southern Economic Journal, 55 (Oct.).

Albrecht, J, et.al. 1989, MOSES Code, IUI, Stockholm

Arrow, K.J. 1962b, Economic Welfare and the Allocation of Resources for Inventions; in Nelson, R. (ed.), 1962, Rate and Direction of Inventive Activity: Economic and Social factors. NBER, Princeton University Press, Princeton.

Arrow, K.J. 1962b i WP 235, Economic Welfare and the Allocation of Resources for Inventions: in Nelson, R (ed.), 1962, Rate and Direction of Inventive Activity: Economic and Social Factors. NBER, Princeton University Press, Princeton.

Audretsch, D.B.-Acs, Z.J, 1990, Technological regimes, Learning and Industry Turbulence, paper prepared to the J.A. Schumpeter conference, Airline House, Virginia, June 1990.

Baldwin, J.R.-Gorecki, P.K., 1987, Plant Creation vs Plant Acquisition: The Entry Process in Canadian Manufacturing, International Journal of Industrial Organization, Vol. 5, pp. 27-42

Baldwin, J.R.-Gorecki, P.K., 1988, Productivity growth and the Competitive Process: The Role of Firm and Plant Turnover, Mimeo to be published in Gorecki-Schwalbach (eds.), Entry and Market Contestability; An International Comparison 1990, Basil Blackwell.

Baldwin, J.R.-Gorecki, P.K., 1989a, Job Turnover in Canada's Manufacturing Sectors, Statistics Canada, Analytical Studies Branch, Research paper series, No. 22.

Baldwin, J.R.-Gorecki, P.K., 1989b, Firm Entry and Exit in the Canadian Manufacturing Sector, Statistics Canada, Analytical Studies Branch, Research paper series, No. 23.

Baldwin, J.R.-Gorecki, P.K., 1990a, The Contribution of the Competitive Process to Productivity Growth - The Role of Firm and Plant Turnover, Statistics Canada, Analytical Studies Branch Research paper series, No. 28.

Baldwin, J.R.-Gorecki, P.K., 1990b, Mergers and the Competitive Process, Research Report No. 23E, Research Paper Series, Statistics Canada.

Baldwin, J.R.-Gorecki, P.K. 1990c, The Relationship between Mobility and Concentration for the Canadian Manufacturing Sector, Working paper, Business and Labor Market Analysis Group, Statistics Canada.

Baldwin, J.R.-Gorecki, P.K. 1990d, Concentration Statistics as Predictors of the Intensity of Competition, Working Paper.

Baldwin, J.R.-Gorecki, P.K. 1990e, Structural Change and the Adjustment Process - Perspectives on Firm Growth and Worker Turnover, A study prepared for Statistics Canada and the Economic Council of Canada.

Baumol, W.J., 1982, Contestable Markets: An Uprising in the Theory of Industry Structure, American Economic Review, (March) pp. 1-15. 
Baumol, W.J.-Panzar, J.C.-Willing, R.D., 1982, Contestable Markets and the Theory of Industry Structure, Harcour Brace Jovanovik, San Diego.

Carlsson, B., 1989a, The Evolution of Manufacturing Technology and its Impact on Industrial Structure: An International Study, Small Business Economics, 1(1), pp. 21-37

Carlsson, B.(ed.), 1989b, Industrial Dynamics - Technological, Organizational and Structure Changes in Industries and Firms (Kluwer Academic Publishers) Boston/Dortrecht/London

Clark, J.B., 1887, The Limits of Competition, Political Science Q:2, No. 1, pp. $45-61$.

Dahmén, E., 1950, Svensk industriell företagsverksamhet (1919-1939), IUI, Stockholm, also published in 1970 by the American Economic Association Translation Series under the title "Entrepreneurial Activity and the development of Swedish Industry, 1919-1939".

Dasgupta, P.-Stiglitz, J., 1981, Entry, Innovation, Exit - Towards a Dynamic Theory of Oligopolistic Industrial Structure, European Economic Review, No. 15, pp. 137-158.

Day, R.H., 1986, Disequilibrium Economic Dynamics: A PostSchumpeterian Contribution in Day-Eliasson (1986).

Day, R.H.-Eliasson, G. (eds.), 1986, The Dynamics of Market Economies, IUI, Stockholm, North Holland, Amsterdam.

de Jong, H.W., 1989, Free Versons Controlled Competition, in Carlsson (1989).

Dunne, T.-Roberts, M.J.-Samuelson, L., 1988, Patterns of Firm Entry and Exit in U.S. Manufacturing Industries, The RAND Journal of Economics, Vol. 19, No.4. (Winter)

Du Rietz, G., 1975, Etablering, nedläggning och industriell tillväxt i Sverige, 1959-1970, IUI, Stockholm.

Du Rietz, G., 1980, Företagsetableringen i Sverige under Efterkrigstiden, IUI, Stockholm.

Eliasson, G., 1977, Competition and Market Processes in a Simulation Model of the Swedish Economy, American Economic Review, Vol. 67, No. 1, February 1977.

Eliasson, G., 1978, A Micro-to-Macro Model of the Swedish Economy, IUI Conference Reports 1978:1.

Eliasson, G., 1983, On the Optimal Rate of Structural Adjustment in Eliasson-Sharefkin-Ysander (1983).

Eliasson, G., 1984, Micro Heterogeneity of Firms and the Stability of Industrial Growth in JEBO Vol. 5 (Sept-Dec).

Eliasson, G., 1985, The Firm and Financial Markets in the Swedish Micro-to-Macro Model, IUI, Stockholm.

Eliasson, G., 1987, Technological Competition and Trade in the Experimentally Organized Economy, IUI Research Report No. 32, Stockholm.

Eliasson, G., 1988, The Firm as a Competent Team, IUI Working Paper No. 207, Stockholm. To be published in JEBO 1990 (July).

Eliasson, G., 1989, Modeling Long-Term Macroeconomic Growth as a Micro-based, Path Dependent, Experimentally Organized Economic Process, IUI Working Paper No. 220.

Eliasson, G., 1990a, The Firm, Its Objectives, Its Controls, and Its Organization, IUI Working Paper. 
Eliasson, G., 1990b, Business Competence, Organizational Learning and Economic Growth, paper presented to the 1990 Joseph A Schumpeter Society meeting in Airlie House, Virginia, USA, June 3-5, 1990.

Eliasson, G.-Sharefkin M.-Ysander, B.-C. (eds.), 1983, Policy Making in a Disorderly World Economy, IUI Conference Reports 1983:1, Stockholm.

Englund, P., 1980, Nyetablering och Marknadstillväxt - en jämnviktstillväxtsmodell, Appendix s. 110-114 i Du Rietz (1980).

Eriksson, G., 1984, Growth, Entry and Exit of Firms, The Scandinavian Journal of Economics, Vol. 86(1), pp. 52-67.

Granstrand, O., 1986, Measuring and Modeling Innovative New Entry, in Day-Eliasson (1986).

Granstrand, O.-Sjölander, S., 1990, The Acquisition of Technology and Small Firms by Large Firms, JEBO (July).

Hanson, K., 1986, On New Firm Entry and Macro Stability, in The Economics of Institutions and Markets, IUI Yearbook 1986-1987, IUI Stockholm 1986.

Hanson, K., 1989, Firm Entry in MOSES Code, Albrecht et.al. (1989).

Hause, J.C.-Du Rietz, G., 1984, Entry, Industry Growth, and the Microdynamics of Industry Supply, JPE Vol. 92, No. 4 (Aug.), pp. 733-757.

Highfield, R.-Smiley R., 1987, New Business Starts and Economic Activity An Equilibrium Investigation, International Journal of Industrial Organization, Vol. 5, pp. 51-66.

Jagrén, L., 1988, Företagens Tillväxt i ett Historiskt Perspektiv i Expansion, Avveckling och Företagsvärdering i Svensk Industri, IUI, Stockholm.

Jenner, R.H., 1966, An Information Version of Pure Competition, Economic Journal, Vol. 76, pp. 786-805.

Jovanovic, B.-Lach, S., 1989, Entry, Exit, and Diffusion with Learning by Doing, American Economic Review, Vol. 79, No. 4 (Sept.), pp. 690-699.

Lucas, R.E., 1967, Adjustment Costs and the Theory of Supply, JPE (Aug.).

Lundell, J., 1846, Om hantverksskrån, näringsfrihet och arbetsorganisation, (About the Guildsystem, Free Entry and the Organization of Work) Lund.

Mansfield, E., 1962, Entry, Gibrat's Law, Innovation and the Growth of Firms, AER 52, pp. 1023-1030.

Modigliani, F., 1958, New Developments on the Oligopolicy Front, JPE 66, pp. 215-232.

Schwalbach, J., 1987, Entry by Diversified Firms into German Industries, International Journal of Industrial Organization, Vol. 5, pp. 43-49.

Shepherd, W.G., 1984, Contestability vs Competition, AER 74, pp. $572-587$.

Stigler, G.J., 1968, A Note on Profitability, Competition and Concentration Chapter 15 in Stigler 1968, The Organization of Industry, (The University of Chicago Press) Chicago \& London

Spence, M., 1976, Product Selection, Fixed Costs and Monopolistic Competition, The Review of Economic Studies, Vol. XLIII (2) No. 134 (June) pp. 217-236.

Winter, S., 1984, Schumpeterian Competition in Alternative Technological Regimes JEBO Vol. 5 (Sept-Dec). 